\title{
Effects of Topical Tetracycline in Wound Healing on Experimental Diabetes in Rats
}

\author{
Cristiano Nakao, Miguel Angel, Sala Di Mateo and Marilena Chinali Komesu*
}

Department of Morphology, Stomatology and Physiology, Ribeirão Preto, School of Dentistry, University of São Paulo, São Paulo, Brazil

\begin{abstract}
A common complication of diabetes is impaired wound healing. Systemic tetracycline improves healing in diabetics, but causes adverse side affects. There are no informations regarding topical tetracyclin use. OBJECTIVES: The objective of this study was to evaluate the effects of topical tetracycline on wound healing. METHODS: Diabetes was induced in Wistar rats by alloxan use. The control group comprised age-matched animals not submitted to alloxan injection. Diabetic state was confirmed by glycosuria and hyperglycemia. Under tribromoethanol anesthesia, four skin wounds (4mm diameter), were performed on shaved dorsal area (2 each side of median line). Topical tetracycline was applied daily only on both wounds on right side of median line. Animals were sacrificed on day 3 or 7 after surgery and tissue samples were prepared and observed under light microscopy. Histological, histometric and stereological methods were used for analysis. RESULTS: Topical tetracycline accelerated wound closure in diabetic compared to nondiabetic rats. No expressive effects were observed in controls. CONCLUSION: Topical tetracycline could be helpful in diabetics, in order to improve the wound healing process avoiding possible adverse effects from systemic medication. Furthermore, there was no indication that tetracycline improoves wound healing on controls.
\end{abstract}

Keywords: Wound healing, tetracycline, tetracyclin, diabetic rats, experimental diabetes.

\section{INTRODUCTION}

Diabetes Mellitus is a syndrome more than a disease, and affects about 150 million people worldwide [1-4]. Metabolic disorders and higher infection susceptibility are its clinical signs. Studies have shown delayed wound healing in diabetics due to cell proliferation deficiency, infection, decreased cell surviving, and reduced wound contraction [58]. The initial inflammatory response on healing areas is also delayed or deficient, mostly in uncontrolled diabetes $[3,9]$.

Diabetes can be experimentally produced in animals by Streptozocin or alloxan i.v. (intravascular) and injection of alloxan monohydrate produces insulin decreasing and hyperglycemia in a few days $[10,11]$. Many human characteristics of diabetes was observed in alloxan diabetic rats [12].

Collagen is also an essential part of wound healing [13]. Diabetic rats show non-enzymatic collagen glucosylation twice that as much than normal rats, associated to deficiency in collagen synthesis during wound healing $[2,11,14]$.

Tetracycline has been used as antimicrobial agent for a long time, but more than that, its ability to inhibit mammalian collagenase activity has been observed. Studies have shown decreased collagenase activity and increased repair by systemic tetracycline [15]. MOSKOW and TANNENBAUM (1991) also observed repair and

*Address correspondence to this author at the Department of Morphology, Stomatology and Physiology, Faculdade de Odontologia de Ribeirão Preto, University of São Paulo, Via do Café - s/n, Campus da USP - RP, 14.040904 Ribeirão Preto, São Paulo, Brazil; Fax: 55-16-633-0999;

E-mail: mckomesu@usp.br regeneration improvement in a group of diabetics that was given systemic tetracycline [15].

So, in general, wound healing deficiency is a very common complication in diabetics and it has been observed that: 1) decreased collagen concentration [16];2) tetracycline may inhibit collagenase [14]; and 3) insulin may also have some beneficial effect on wound healing [2].

Our study uses topical tetracycline, in diabetic and control animals, and evaluate the wound healing process. This procedure is used to avoid the adverse effects of systemic tetracyclin, such as increased skin pigmentation, discoloration of nails and teeth, uremia, headache, enteritis and inappetence, among other effects [17].

The general objective of this work is to evaluate the effects of topical tetracycline on surgical wound healing process. The specific objectives are: 1) Evaluate the initial phases of wound healing in the skin of normal and diabetic animals; and 2) Compare wound healing areas in diabetics and their controls after local tetracycline use.

\section{MATERIALS AND METODS}

White Wistar rats (Rattus norvegicus) were separated into groups as follows: Group I - 10 control animals - Group Ia - 5 animals sacrificed 3 days after surgery; and Group Ib 5 animals sacrificed 7 days after surgery. Group II - 10 diabetic animals without insulin therapy - Group IIa - 5 animals sacrificed 3 days after surgery; and Group IIb - 5 animals sacrificed 7 days after surgery. Group III - 10 diabetic animals on insulin therapy - Group IIa - 5 animals sacrificed 3 days after surgery; and Group IIb - 5 animals sacrificed 7 days after surgery.All animals were kept, during the whole experimental period in plastic boxes $(40 \mathrm{x} 32 \mathrm{x}$ $17 \mathrm{~cm})$ under controlled light conditions (12 hours of light; 
12 hours of darkness) and temperature $\left(21-25^{\circ} \mathrm{C}\right)$, at the Ribeirão Preto school of Dentistry (FORP-USP).

\section{Diabetes Production}

After 36 hours of food deprivation, the diabetic group were i.v. Alloxan injected (40 mg/kg of body weight). 30 minutes after injection, food and water were offered again. The injected animals were controlled 4 days after injection to verify the presence of glicosuria(test tape). All animals with comproved glucosuria were considered diabetic. Animals with similar age and weight were controls. The animals with diabetes were separated into 2 groups - without insulin (Group II) and on insulin therapy (Group III).

\section{Insulin Therapy}

Subcutaneous injection of insulin ( $0.1 \mathrm{U}$ long duration insulin Humulin-Lilly ${ }^{\mathrm{TM}}$ ), $100 \mathrm{~g}$ body weight every two days. The Group III animals were kept under insulin therapy for 15 days before wound surgery.

\section{Experimental Wound}

All the animals suffered dorsal surgery as described: after anesthesia (2,2,2-Tribromoethanol Aldrich, 25mg/100g body weight - intraperitoneal injection) and after removed the hair from the dorsal skin, 4 skin wounds were prepared (4 $\mathrm{mm}$ diameter) approximately $2 \mathrm{~cm}$ from each other (modification from MUSTOE et al., 1987 [18], WHITBY \& FERGUSON, 1991 [19], and MOST et al., 1996 [20]). Povidone-iodine was used as topical anti-infective. Half of the wounds received topical application of tetracycline $\left(\mathrm{EMS}^{\circledR}\right)$ daily until sacrifice; iodine solution was applied immediately after surgery in the remainder. All the animals also received veterinary pentabiotic, $(0.4 \mathrm{ml}$ intramuscular -Fort Dodge $\left.{ }^{\circledR}\right)$, immediately after surgery.

\section{Sacrifice and Collection of Material}

Animals were sacrificed by cardiac and respiratory breakdown during surgery, when anesthetized. Healing tissues were removed and fixed (formalin 10\% - 24 hours). Glycemia were measured at the moment of sacrifice using a Glucometer Elite (Bayer ${ }^{\circledR}$ ).

\section{Histological Technique}

The tissues were dehydrated and paraffin embedded. Slides were prepared ( $6 \mu \mathrm{m}$ thickness) and placed on glass lamina to be properly staining.

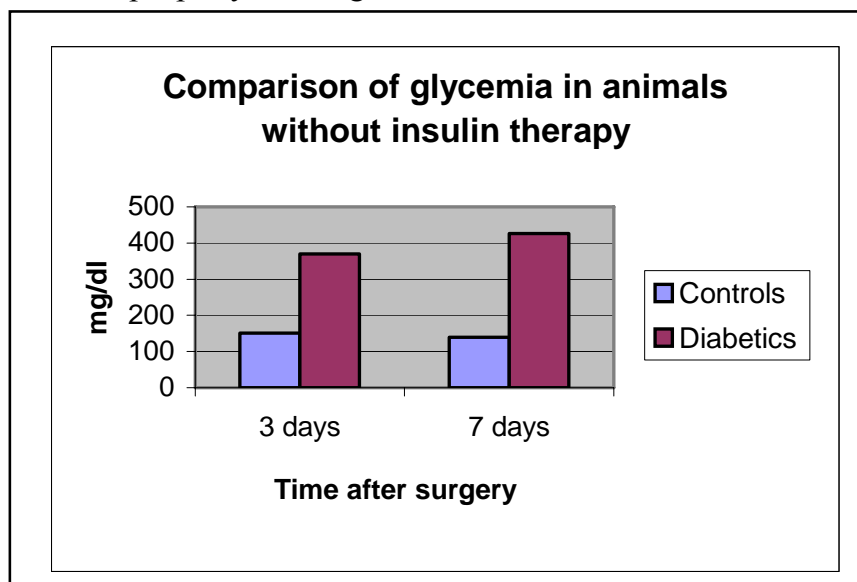

\section{Morphometric and Statistical Analysis}

HE were used for routine histological evaluation of tissues in healing area. A tricromic stain (for platelets and fibrin, according to BEHMER et al., 1986) were used in the evaluation of collagen formation, using the color differences - blue for collagen and platelets; red for fibrin; yellow for erytrocytes. The epithelial neoformation is calculated (in percent of area) based on percent of points using an 100 points grade. The healing periods observed were 3 and 7 days after surgery, and 10 different healing areas are observed, as a modification of Chalkley's method [21]. An image analiser software (KS200) were used for collagen evaluation [22]. The collected data is presented as mean values and Mann-Whitney test was used to compare groups. $P$ values $<0.05$ are considered statistically significant.

\section{RESULTS}

\section{Evaluation of Diabetes}

Animals with glycemia $>200 \mathrm{mg} / \mathrm{dl}$ were considered diabetic, according to NAGY et al., 1961 [23]. Hiperglycemia were observed in all diabetic animals. Mean blood glucose levels $(360 \mathrm{ml} / \mathrm{dl}$ on day 3 and $426 \mathrm{mg} / \mathrm{dl}$ on day 7 after surgery) compared with non-diabetic animals $(151 \mathrm{mg} / \mathrm{dl}$ on day 3 and $139 \mathrm{mg} / \mathrm{dl}$ on day 7 after surgery) are shown in Fig. (1) and Table $\mathbf{1}$.

\section{Macroscopic Results}

Initial macroscopic evaluation is shown in Figs. (2, 3). Wound healing process in diabetic animals with (right side) and without (left side) topical tetracycline.

Macroscopic evaluation of healing area (days 3 and 7 after surgery) shows a very clear beneficial effect of topical tetracycline on the healing process in diabetics. A well marked difference in the epithelial neoformation (days 3 and 7 after surgery) can be observed following use of tetracycline.

\section{Histopathological Results}

\section{Evaluation of Epithelial Neoformation}

The epithelial neoformation was evaluated taking as parameters: a) diabetics, without tetracycline treatment (Fig. 4); b) topical tetracycline in controls (Fig. 5); and c) topical tetracycline in diabetics (Figs. 6, 7) and Table 2.

\section{Comparison of glycemia in animals with insulin therapy}

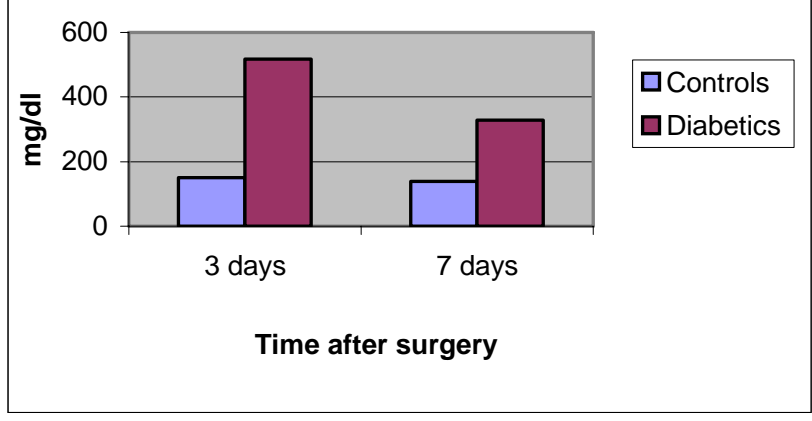

Fig. (1). Comparison of control and diabetic animals, on days 3 and 7 after surgery. 
The results show that diabetes caused a delay in the epithelial neoformation in the healing area. Figs. (5-7) show the epithelial neoformation in control (Fig. 5) and diabetic animals (Figs. 6,7) after topical tetracycline.

Table 1. Blood Glucose Evaluation (mg/dl)

\begin{tabular}{|c|c|c|}
\hline \multicolumn{3}{|c|}{ Animals without Insulintherapy } \\
\hline Controls & Day 3 After Surgery & Day 7 After Surgery \\
\hline 105 & 406 & 464 \\
\hline 177 & 445 & 251 \\
\hline 134 & 518 & 441 \\
\hline 155 & 214 & 509 \\
\hline 186 & 268 & 465 \\
\hline $151 \mathrm{mg} / \mathrm{dl}$ & $370 \mathrm{mg} / \mathrm{dl}$ & $426 \mathrm{mg} / \mathrm{dl}$ \\
\hline $\begin{array}{l}\text { TEST U - MANN } \\
\text { WHITNEY }\end{array}$ & $\begin{array}{l}\text { U Calc. }=0 * \\
P[U]=0.004\end{array}$ & $\begin{array}{l}\mathrm{U} \text { calc. }=0 * \\
\mathrm{P}[\mathrm{U}]=0.004\end{array}$ \\
\hline \multicolumn{3}{|c|}{ Animals With Insulintherapy } \\
\hline Controls & Day 3 After Surgery & Day 7 After Surgery \\
\hline 105 & 579 & 453 \\
\hline 177 & 600 & 251 \\
\hline 134 & 385 & 233 \\
\hline 155 & 481 & 495 \\
\hline 186 & 542 & 209 \\
\hline $151 \mathrm{mg} / \mathrm{dl}$ & $517 \mathrm{mg} / \mathrm{dl}$ & $328 \mathrm{mg} / \mathrm{dl}$ \\
\hline $\begin{array}{l}\text { TEST U - MANN } \\
\text { WHITNEY }\end{array}$ & $\begin{array}{l}\text { U Calc. }=0 \text { * } \\
P[U]=0.004\end{array}$ & $\begin{array}{l}\text { U calc. }=0 \text { * } \\
P[U]=0.004\end{array}$ \\
\hline
\end{tabular}

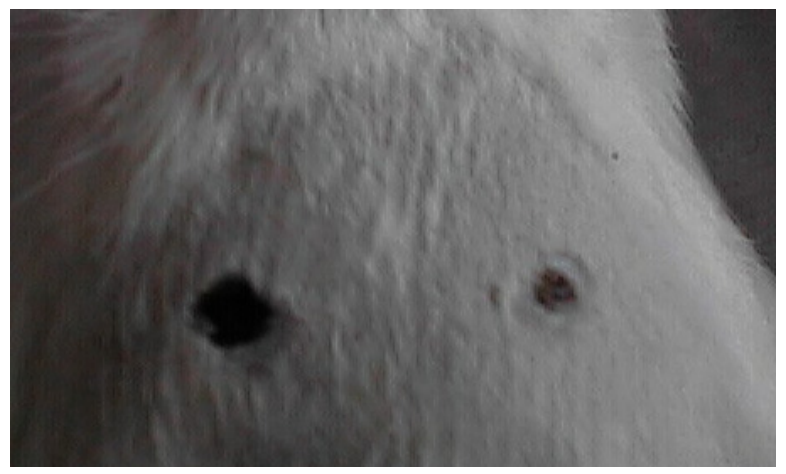

Fig. (2). Healing area in diabetic animal, day 3 after surgery, observe the improved cicatrization at right side wound.

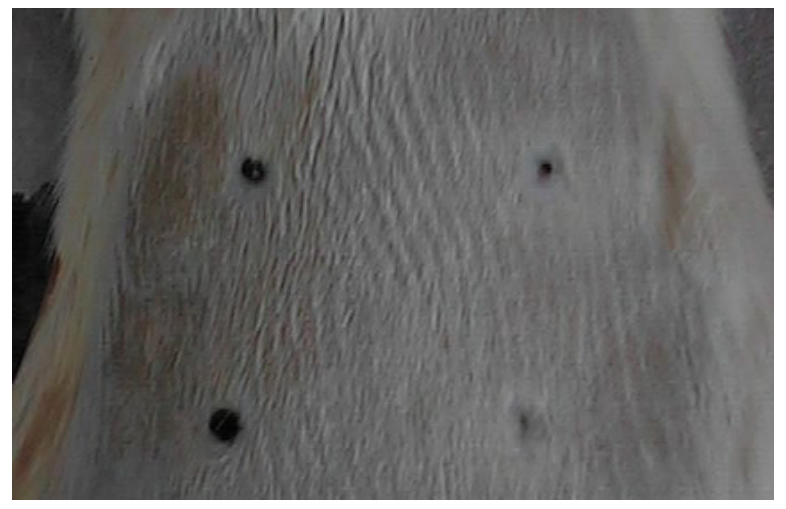

Fig. (3). Healing area in diabetic animal, day 7 after surgery. Observe the difference on surgical areas at the right side.

The results showed that:

1. diabetic animals presented a delayed epithelial neoformation;

2. topical tetracycline use is associated with an improvement in the wound healing of diabetic animals; and

3. there was no evidence indicating an effect of topical tetracycline in controls.

\section{Evaluation of Collagen Formation}

The collagen formation in healing area was evaluated woth special stains (Trichromic for platelet and fibrin, according to described in Behmer et al., 1976). The medium values obtained by evaluating the quantity of collagen appeared in healing areas are expressed in next Figures and Tables.

Observe that diabetic animals present a remarkable deficiency of collagen at $7^{\text {th }}$ day after surgery (Figs. 8, 9). The obtained results allow us to observe that:

1. the collagen deficiency at day 3 after surgery is statistically significant among animals with initial diabetes (without insulin therapy) as shown in Table 3;

2. in animals on insulinthera the diffeerence of collagen content in areas of healing tend to be less expressive as the one observed in controls.

\section{DISCUSSION AND CONCLUSION}

Studies have shown that many factors are associated to the deficiency in healing process in diabetics, and the deficiency in collagen synthesis is one of them. Deficiency in collagen deposition in healing areas was observed in our study when comparing control and diabetic animals. Deficiency in epithelial neoformation was also observed.

Hyperglycemia, a clinical marker of diabetes, was evident in our experimental diabetic animals, with and without insulin therapy every two days, and one important point to be ovserved is the that despite insulin therapy, the blood glucose level in many diabetic patients do not match the controlled levels achieved in normal individuals (as observed in our animals). In our animals it was possible to observe healing and epithelial neoformation delay (Fig. 4).

Tetracycline, by beiong liberated in oral fluids and by its anticollagenolytic effects, is important for periodontal tissue repair. Studies showed improvement in repairing conditions of periodontal tissues, but as inconvenient, some collateral effects, due to systemic administration such as some gastrointestinal discomfort, diarrhea, increased skin and tooth pigmentation and uremia $[12,15,17,24,25]$.

It was possible to observe that tetracycline, and insulin, present benefic effects in collagen formation in healing area. Comparing the wound healing in diabetic and control animals, we observed that topical tetracycline resulted in faster healing in diabetic animals and this was most evident during the initial phases of the healing process - day 3 after surgery. 
Table 2. Mean Value of the Percent of Points on Epithelium and Pseudomembrane ub Wounded Areas in Diaberic Animals and Their Controls were Evaluated Wounded Areas with (w/tcl) and wihtout (out/tcl) Tetracyclin Topical Treatment

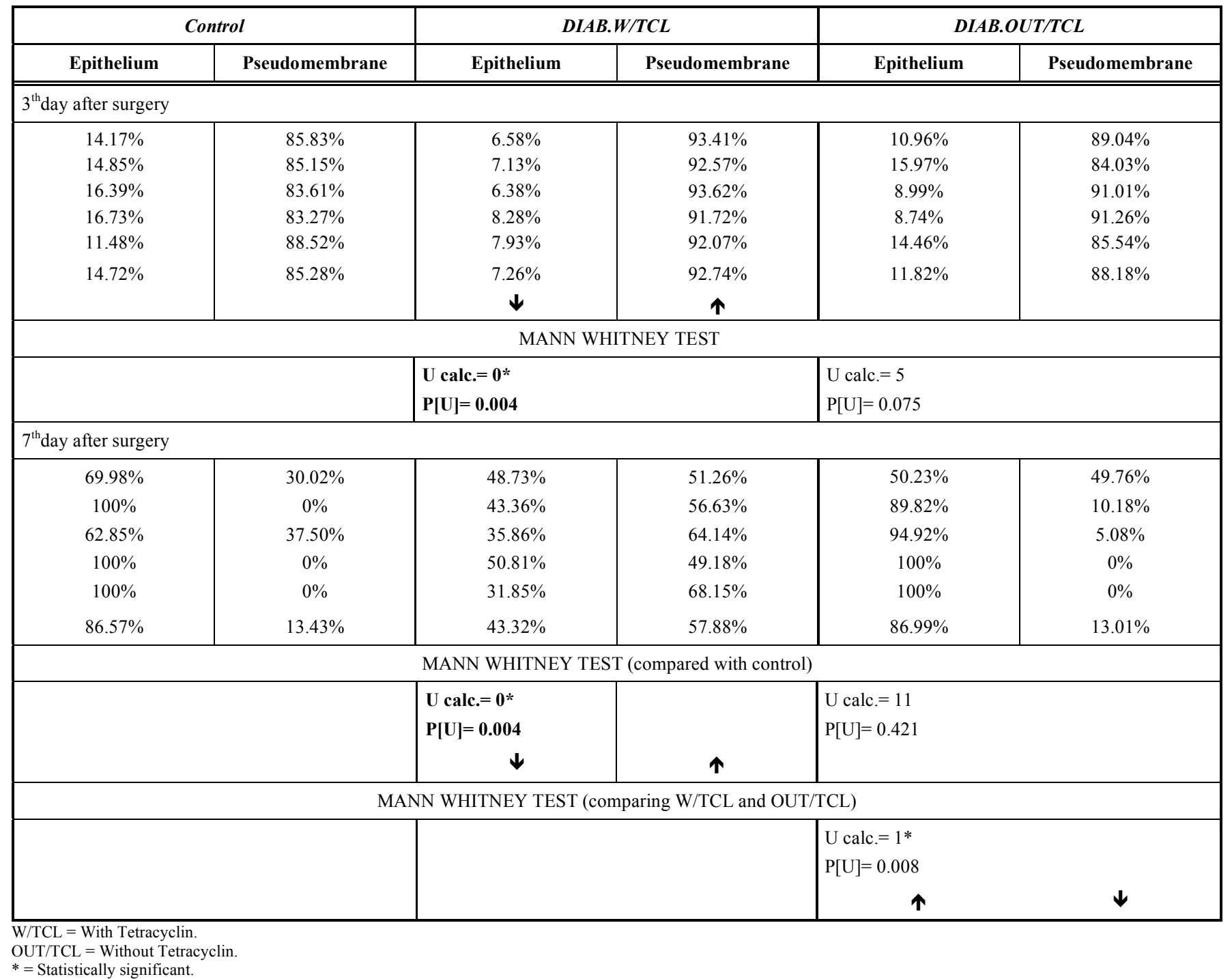

Our results showed that topical tetracycline rendered the healing in diabetic animals near to that observed in controls. It was very interesting to observe that, in spite of tetracycline re-establishing the velocity of healing in diabetic animals we did not observe any significant effects of topical tetracycline in the controls. Probably tetracyclin effects are exactly the one necessary for diabetic healing deficiency.

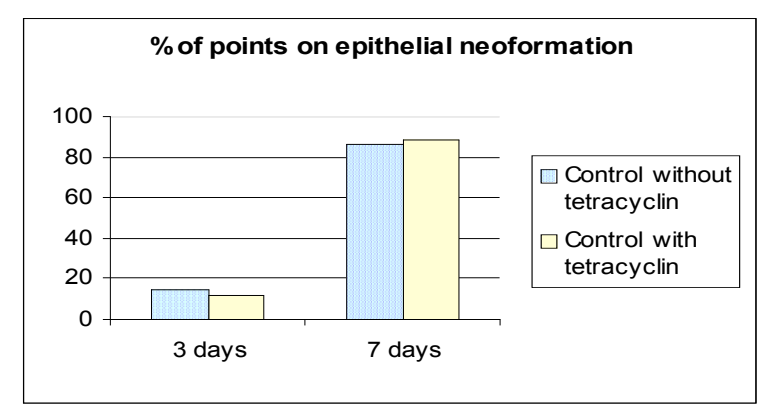

Fig. (4). Evaluation of relative percentage of points in neoformed epithelium surgical areas of control animals with and without topical application of tetracycline.

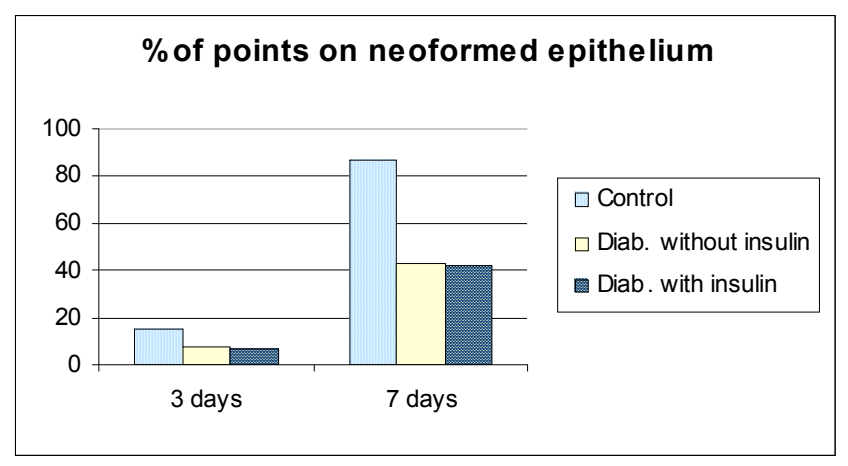

Fig. (5). Evaluation of relative percentage of points observed on neoformed epithelium on on surgery area of control and diabetic animals, with and without insulintherapy.

Another important aspect is to observe the role of insulin in wound healing. The insulin is very important in controlling the glycemia of mammalian, however has also an important role in the healing process (as observed in Tables 3 and 4). The results of wound healing showed the important 
role of insulin as a promoter of healing, even in when the animals are still hyperglycemic.

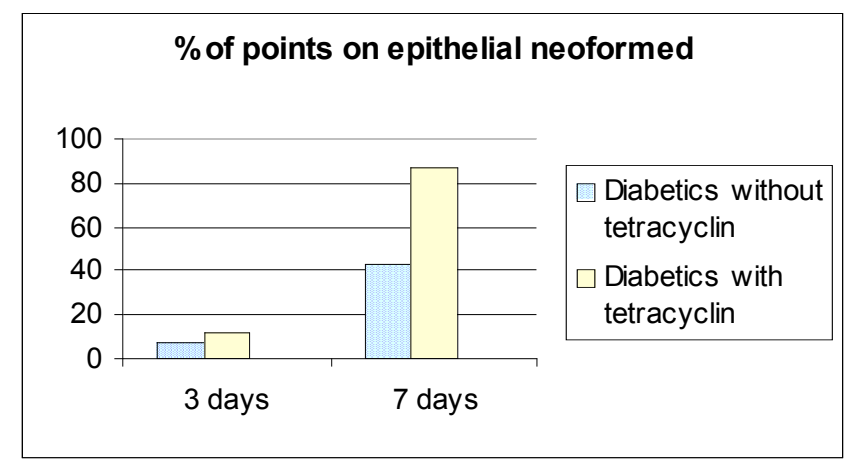

Fig. (6). Evaluation of points on epithelial neoformation on surgical areas of diabetic animals (without insulin therapy) with and without topical tetracycline.

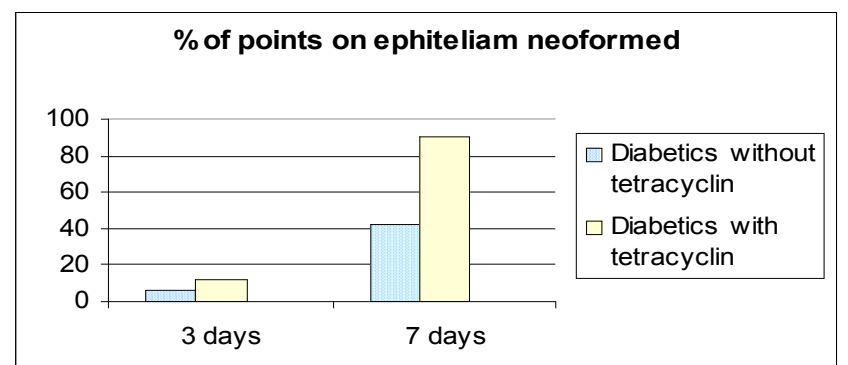

Fig. (7). Evaluation of points on epithelial neoformation on surgical areas of diabetic (on insulin therapy) with and without topical tetracycline.

Our results allow to conclude that:

1. diabetic animals, as soon short duration diabete as long duration diabetes, really show a deficiency of healing, compared to controls;

Table 3. Collagen Evaluation in Healing Areas with Tetracyclin (W/TCL) and without Tetracyclin (OUT/TCL) on Day 3 After Surgery

\begin{tabular}{|c|c|c|c|c|c|}
\hline \multicolumn{3}{|c|}{ OUT/TCL } & \multicolumn{3}{|c|}{ W/TCL } \\
\hline Density & Area & $\%$ of Area & Density & Area & $\%$ of Area \\
\hline \multicolumn{6}{|l|}{ Controls } \\
\hline $2510 \times 10^{3}$ & $11.7 \times 10^{3}$ & $6.47 \%$ & $3724 \times 10^{3}$ & $17.4 \times 10^{3}$ & $9.60 \%$ \\
\hline $3394 \times 10^{3}$ & $15.9 \times 10^{3}$ & $8.75 \%$ & $3227 \times 10^{3}$ & $15.1 \times 10^{3}$ & $8.32 \%$ \\
\hline $3092 \times 10^{3}$ & $14.5 \times 10^{3}$ & $7.97 \%$ & $3027 \times 10^{3}$ & $14.2 \times 10^{3}$ & $7.80 \%$ \\
\hline $2965 \times 10^{3}$ & $13.9 \times 10^{3}$ & $7.65 \%$ & $3981 \times 10^{3}$ & $18.7 \times 10^{3}$ & $10.26 \%$ \\
\hline $3619 \times 10^{3}$ & $17.0 \times 10^{3}$ & $9.34 \%$ & $4433 \times 10^{3}$ & $20.8 \times 10^{3}$ & $11.43 \%$ \\
\hline $3116 \times 10^{3}$ & $14.6 \times 10^{3}$ & $8.03 \%$ & $3678 \times 10^{3}$ & $17.2 \times 10^{3}$ & $9.48 \%$ \\
\hline \multicolumn{6}{|c|}{ Diabetic without Insulintherapy } \\
\hline $1243 \times 10^{3}$ & $5.8 \times 10^{3}$ & $3.20 \%$ & $2236 \times 10^{3}$ & $10.5 \times 10^{3}$ & $5.76 \%$ \\
\hline $2236 \times 10^{3}$ & $10.5 \times 10^{3}$ & $5.76 \%$ & $2359 \times 10^{3}$ & $11.0 \times 10^{3}$ & $6.08 \%$ \\
\hline $2150 \times 10^{3}$ & $10.1 \times 10^{3}$ & $5.54 \%$ & $2440 \times 10^{3}$ & $11.4 \times 10^{3}$ & $6.29 \%$ \\
\hline $2251 \times 10^{3}$ & $10.6 \times 10^{3}$ & $5.81 \%$ & $2208 \times 10^{3}$ & $10.3 \times 10^{3}$ & $5.69 \%$ \\
\hline $1975 \times 10^{3}$ & $9.2 \times 10^{3}$ & $5.09 \%$ & $2956 \times 10^{3}$ & $13.8 \times 10^{3}$ & $7.62 \%$ \\
\hline $1971 \times 10^{3}$ & $9.2 \times 10^{3}$ & $5.08 \%$ & $2439 \times 10^{3}$ & $11.4 \times 10^{3}$ & 6.28 \\
\hline \multicolumn{6}{|c|}{ U TEST - MANN WHITEY } \\
\hline $\begin{array}{l}\mathrm{U} \text { calc }=0 * \downarrow \\
\mathrm{P}[\mathrm{U}]=0.004\end{array}$ & & & $\begin{array}{l}\mathrm{U} \text { calc }=0 * \downarrow \\
\mathrm{P}[\mathrm{U}]=0.004\end{array}$ & & \\
\hline \multicolumn{6}{|c|}{ Diabetic with Insulintherapy } \\
\hline $2526 \times 10^{3}$ & $11.8 \times 10^{3}$ & $6.51 \%$ & $4849 \times 10^{3}$ & $22.7 \times 10^{3}$ & $12.50 \%$ \\
\hline $2946 \times 10^{3}$ & $13.8 \times 10^{3}$ & $7.59 \%$ & $6560 \times 10^{3}$ & $30.8 \times 10^{3}$ & $16.92 \%$ \\
\hline $3090 \times 10^{3}$ & $14.5 \times 10^{3}$ & $7.97 \%$ & $6817 \times 10^{3}$ & $32.0 \times 10^{3}$ & $17.58 \%$ \\
\hline $2400 \times 10^{3}$ & $11.3 \times 10^{3}$ & $6.19 \%$ & $6362 \times 10^{3}$ & $29.8 \times 10^{3}$ & $16.41 \%$ \\
\hline $2956 \times 10^{3}$ & $13.8 \times 10^{3}$ & $7.62 \%$ & $5323 \times 10^{3}$ & $25.0 \times 10^{3}$ & $13.73 \%$ \\
\hline $2783 \times 10^{3}$ & $13.0 \times 10^{3}$ & $7.77 \%$ & $5982 \times 10^{3}$ & $28.0 \times 10^{3}$ & 15.43 \\
\hline \multicolumn{6}{|c|}{ U TEST- MANN WHITNEY (Compared to controls) } \\
\hline $\mathrm{U}$ calc $=5 \mathrm{~ns}$ & & & $\mathrm{U}$ calc $=0$ * $\uparrow$ & & \\
\hline$P[U]=0.075$ & & & $\mathrm{P}[\mathrm{U}]=0.004$ & & \\
\hline \multicolumn{6}{|c|}{ U TEST- MANN WHITNEY (Compared to diabetic without insulintherapy) } \\
\hline $\begin{array}{l}\mathrm{U} \text { calc }=0 * \uparrow \\
\mathrm{P}[\mathrm{U}]=0.004\end{array}$ & & & $\begin{array}{l}\mathrm{U} \text { calc }=0 * \uparrow \\
\mathrm{P}[\mathrm{U}]=0.004\end{array}$ & & \\
\hline
\end{tabular}


Table 4. Collagen Evaluation in Healing Areas. Without Tetracyclin (OUT/TCL) and with Tetracyclin (W/TCL) on Day 7 After Surgery

\begin{tabular}{|c|c|c|c|c|c|}
\hline \multicolumn{3}{|c|}{ OUT/TCL } & \multicolumn{3}{|c|}{ W/TCL } \\
\hline Density & Area & $\%$ of Area & Density & Area & \% of Area \\
\hline \multicolumn{6}{|l|}{ Controls } \\
\hline $\begin{array}{c}9557 \times 10^{3} \\
12680 \times 10^{3} \\
23609 \times 10^{3} \\
9011 \times 10^{3} \\
26209 \times 10^{3} \\
16213 \times 10^{3}\end{array}$ & $\begin{array}{l}51.20 \times 10^{3} \\
68.80 \times 10^{3} \\
103.3 \times 10^{3} \\
47.00 \times 10^{3} \\
111.4 \times 10^{3} \\
76.34 \times 10^{3}\end{array}$ & $\begin{array}{c}28.12 \% \\
37.7 \% \\
56.73 \% \\
25.82 \% \\
61.20 \% \\
41.91 \%\end{array}$ & $\begin{array}{l}11720 \times 10^{3} \\
13195 \times 10^{3} \\
12050 \times 10^{3} \\
23373 \times 10^{3} \\
26279 \times 10^{3} \\
17323 \times 10^{3}\end{array}$ & $\begin{array}{c}63.5 \times 10^{3} \\
98.7 \times 10^{3} \\
42.6 \times 10^{3} \\
106.1 \times 10^{3} \\
120.7 \times 10^{3} \\
86.32 \times 10^{3}\end{array}$ & $\begin{array}{l}34.88 \% \\
54.22 \% \\
23.73 \% \\
58.23 \% \\
66.27 \% \\
47.46 \%\end{array}$ \\
\hline \multicolumn{6}{|c|}{ Diabetic without Insulintherapy } \\
\hline $\begin{array}{c}9737 \times 10^{3} \\
6218 \times 10^{3} \\
6862 \times 10^{3} \\
10645 \times 10^{3} \\
11312 \times 10^{3} \\
8954 \times 10^{3}\end{array}$ & $\begin{array}{l}62.2 \times 10^{3} \\
40.4 \times 10^{3} \\
38.9 \times 10^{3} \\
68.1 \times 10^{3} \\
74.4 \times 10^{3} \\
56.8 \times 10^{3}\end{array}$ & $\begin{array}{l}34.20 \% \\
22.23 \% \\
21.38 \% \\
37.44 \% \\
40.89 \% \\
31.22 \% \\
\end{array}$ & $\begin{array}{c}9780 \times 10^{3} \\
7749 \times 10^{3} \\
7929 \times 10^{3} \\
11855 \times 10^{3} \\
9738 \times 10^{3} \\
9410 \times 10^{3}\end{array}$ & $\begin{array}{c}66.2 \times 10^{3} \\
50.8 \times 10^{3} \\
57.2 \times 10^{3} \\
46.8 \times 10^{3} \\
62.2 \times 10^{3} \\
56.64 \times 10^{3}\end{array}$ & $\begin{array}{l}36.30 \% \\
27.90 \% \\
31.44 \% \\
25.74 \% \\
34.21 \% \\
31.11 \% \\
\end{array}$ \\
\hline \multicolumn{6}{|c|}{ U TEST - MANN WHITEY } \\
\hline $\begin{array}{l}\mathrm{U} \text { calc }=6 \mathrm{~ns} \\
\mathrm{P}[\mathrm{U}]=0.111\end{array}$ & & & $\begin{array}{l}\mathrm{U} \text { calc }=1 * \downarrow \\
\mathrm{P}[\mathrm{U}]=0.008\end{array}$ & & \\
\hline \multicolumn{6}{|c|}{ Diabetic with Insulintherapy } \\
\hline $\begin{array}{l}12094 \times 10^{3} \\
10742 \times 10^{3} \\
11011 \times 10^{3} \\
11430 \times 10^{3} \\
10906 \times 10^{3} \\
11236 \times 10^{3}\end{array}$ & $\begin{array}{l}65.0 \times 10^{3} \\
46.0 \times 10^{3} \\
69.3 \times 10^{3} \\
69.3 \times 10^{3} \\
46.1 \times 10^{3} \\
59.14 \times 10^{3}\end{array}$ & $\begin{array}{l}35.71 \% \\
26.24 \% \\
38.08 \% \\
38.08 \% \\
25.90 \% \\
32.80 \%\end{array}$ & $\begin{array}{l}12898 \times 10^{3} \\
10703 \times 10^{3} \\
12552 \times 10^{3} \\
11248 \times 10^{3} \\
13196 \times 10^{3} \\
12119 \times 10^{3}\end{array}$ & $\begin{array}{c}87.9 \times 10^{3} \\
58.1 \times 10^{3} \\
75.9 \times 10^{3} \\
70.5 \times 10^{3} \\
98.7 \times 10^{3} \\
78.22 \times 10^{3}\end{array}$ & $\begin{array}{l}48.31 \% \\
31.90 \% \\
41.72 \% \\
38.75 \% \\
54.22 \% \\
42.98 \%\end{array}$ \\
\hline \multicolumn{6}{|c|}{ U TEST - MANN WHITNEY (compared to controls) } \\
\hline $\begin{array}{l}\mathrm{U} \text { calc }=10 \mathrm{~ns} \\
\mathrm{P}[\mathrm{U}]=0.345\end{array}$ & & & $\begin{array}{l}\mathrm{U} \text { calc }=7 \mathrm{~ns} \\
\mathrm{P}[\mathrm{U}]=0.155\end{array}$ & & \\
\hline \multicolumn{6}{|c|}{ U TEST - MANN WHITNEY (compared to diabetic without insulintherapy) } \\
\hline $\begin{array}{l}\mathrm{U} \text { calc }=3 * \uparrow \\
\mathrm{P}[\mathrm{U}]=0.028\end{array}$ & & & $\begin{array}{l}\mathrm{U} \text { calc }=2 * \boldsymbol{\uparrow} \\
\mathrm{P}[\mathrm{U}]=0.016\end{array}$ & & \\
\hline
\end{tabular}

$*=$ Statistically significant.

\section{$\%$ of collagen area}

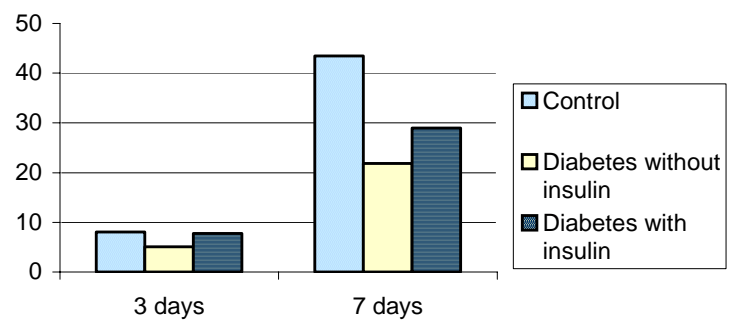

Fig. (8). Graphic representation of collagen presence in healing area of control animals, initial diabetes and long duration diabetes.

2. the use of topical tetracycline could be a helper way to healing process in diabetics without inconvenient of adverse side effects when used in a systemic way; and

3. although the benefic effect of tetracycline on the healing process of diabetic, it wasn't observed benefits that could justify the use of tetracyclin in normal rats, or be it, those that didn't present deficiency of healing.
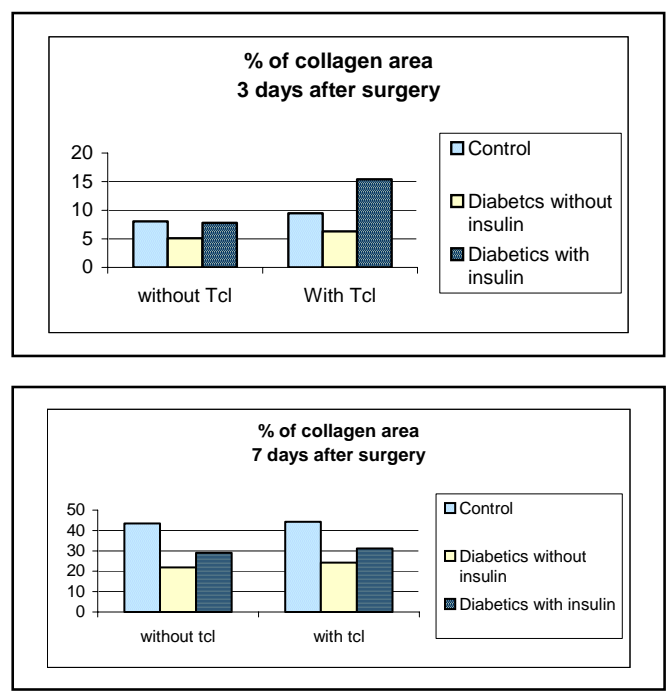

Fig. (9). Comparison of the effects of topical tetracycline (Tcl) through the percentage of collagen in healing area in control animals, diabetics without insulin therapy and diabetics with insulin therapy. 


\section{REFERENCES}

[1] Prakash A, Pandit PN, Sharma LS. Studies in wound healing in experimental diabetes. Intern Surg 1974; 59: 25-8.

[2] Goodson WH, Hunt TK. Wound healing and the diabetic patient. Surg Gynecol Obst 1979; 149: 600-8.

[3] Mordes JP, Rossini AA. Animal models of diabetes. Am J Med 1981; 70: 353-60.

[4] Ptak W, Klimek M, Bryniarski K, Ptak M, Majcher P. Machophage function in alloxan diabetic mice: expression of cadhesion mollecules, generation of monokines and oxygen and NO radicals. Clin Exp Immunol 1998; 114: 13-8.

[5] Nagy S, Rédei A, Karády S. Studies on granulation tissue prodution in alloxan-diabetic rats. J Endocrinol 1961; 22: 143-6.

[6] Greenhalgh D, Srugel KH, Murray MJ, Ross R. PDGF and FGF stimulate wound healing in the genetically diabetic mouse. Am J Pathol 1990; 36: 1235-46.

[7] Loots MAM, Lamme EM, Zeeglaar J, Mekkes JR, Bos JD, Middelkoop E. Differences in cellular infiltrate and extracellular matrix of chronic diabetic and venous ulcers $v s$ acude wounds. J Invest Dermatol 1998; 111: 850-7.

[8] Matsuda H, Koyama H, Sato H, et al. Role of nerve growth factor in cutaneous wound healing: Accelerating effects in normal and healing-impaired diabetic mice. J Exp Med 1998; 187: 297-306.

[9] Pereira MAA, Sanomiya P, Leme JG. Inhibition of leukocyte chemotasis by factor in alloxan-induced diabetic rat plasma. Diabetes 1987; 36: 1307-14.

[10] Darby IA, Bisucci T, Hewitson TD, MacLellan DG. Apoptosis is increased in a model of diabetes - impaired wound healing in genetically diabetic mice. Int J Biochem Cell Biol 1997; 29: 191200.

[11] Ramamurthy NS, Zebrowski EJ, Golub LM. Collagenolytic activity of alloxan diabetic rat gingivae. Diabetes 1973; 22: 272.

[12] Pierce GF, Tarpley JE, Yanagihara D, Mustoe TA, Fox GM, Thomason A. Platelet-derived growth factor (BB homodimer), transforming Growth factor $\beta 1$ and basic fibroblast growth factor in dermal wound healing. Am J Pathol 1992; 140: 1375-88.
[13] Klein DJ. Effects of diabetes on kidney proteoglycans Cap. 15. In: Ruderman N, Williamson J, Brownlee M, Eds. Hyperglycemia, diabetes and vascular disease. Oxford University Press: Oxford (NW) 1992; p. 300.

[14] Golub LM, Lee HM, Lehrer G, et al. Inocycline reduces gingival collagenolytic activity during diabetes. J Period Res 1983; 18: 51626.

[15] Moskow BS, Tannenbaum P. Enhanced repair and regeneration of periodontal lesions in tetracycline-treated patients. J Periodontol 1991; 62: 341-50.

[16] Yue DK, McLennan S, Marsh M, et al. Effects of experimental diabetes, uremia, and malnutrition on wound healing. Diabetes 1987; 36: 295-9.

[17] Somerman MJ, Foster RA, Vorsteg G, Progebin K, Wynn RL. Effects of minocycline on fibroblast attachment ad spreading. J Periodont Res 1988; 23: 154-9.

[18] Mustoe TA, Pierce GF, Thomason A, Gramates P, Sporn MB, Devel TF. Accelerated healing of incisional wounds in rats induced by transforming growth factor- $\beta$. Science $1987 ; 237$ : 1333-6.

[19] Whitby DJ, Ferguson MWJ. Immunohistochemical localization of growth factors in fetal wound healing. Dev Biol 1991; 147: 207-15.

[20] Most D, Hoyt J, Sibley RK, Press BHJ. Parenchymal cytokine expression precedes clinically observed ischemia in dorsal flaps in the rat. Plast Reconst Surg 1996; 98: 856-61.

[21] Chalkley HW. Method for quantitative morphologic analysis of tissues. J Nat Cancer Inst 1943; 4: 47-53.

[22] Behmer AO, Tolosa EMC de, Freitas Neto AG. Manual de técnicas para histologia normal e patológica. EDART - Editora da Universidade de São Paulo: São Paulo (SP) 1976; p. 239.

[23] Nagy S, Redei A, Karády S. Studies on granulation tissue prodution in alloxan-diabetic rats. J Endocrinol 1961; 22: 143-6.

[24] Golub LM, Ramamurthy NS, McNamara TF, et al. Tetracyclines inhibit tissue collagenase activity-A new mechanism in the treatment of periodontal disease. J Period Res 1984; 19: 651-5.

[25] Cummings GR, Torabinejad M. Effect of systemic doxycycline on alveolar bone loss after periradicular surgery. J Endod 2000; 26: $325-7$. 